\title{
Catalyzed alanates for hydrogen storage
}

\author{
K. J. Gross ${ }^{\mathrm{a}}$, G. J. Thomas ${ }^{\mathrm{a}}$ and C. Jensen ${ }^{\mathrm{b}}$ \\ ${ }^{a}$ Sandia National Laboratories, Livermore, CA 94551-0969 U.S.A. \\ ${ }^{b}$ University of Hawaii, Chemistry Department, Honolulu, HI 96822 USA
}

\section{Abstract}

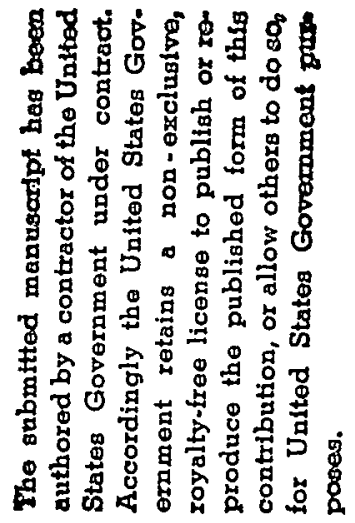

The discovery that hydrogen can be reversibly absorbed and desorbed from complex hydrides (the alanates) by the addition of catalysts has created an entirely new prospect for lightweight hydrogen storage. Unlike the interstitial intermetallic hydrides, these compounds release hydrogen through a series of decomposition / recombination reactions e.g.:

$$
\mathrm{NaAlH}_{4} \Leftrightarrow 1 / 3 \mathrm{Na}_{3} \mathrm{AlH}_{6}+2 / 3 \mathrm{Al}+\mathrm{H}_{2} \Leftrightarrow \mathrm{NaH}+\mathrm{Al}+3 / 2 \mathrm{H}_{2}
$$

Initial work resulted in improved catalysts, advanced methods of preparation and a better understanding of the hydrogen absorption and desorption processes. Recent studies have clarified some of the fundamental material properties as well as the engineering characteristics of catalyst enhanced sodium alanate. Phase transitions observed real-time through in situ Xray powder diffraction demonstrate that the decomposition reactions occur through long-range transport of metal species. SEM imaging and EDS analysis verify aluminum segregation to the surface of the material during decomposition. The equilibrium thermodynamics of decomposition have now been measured down to room temperature. They show a plateau pressure for the first reaction of $1 \mathrm{~atm}$ at $33^{\circ} \mathrm{C}$, which suggest that, thermodynamically, this material is ideally suited to onboard hydrogen storage for fuel cell vehicles. Room temperature desorption with slow but measurable kinetics has been recorded for the first time. Studies at elevated temperatures $\left(125-165^{\circ} \mathrm{C}\right)$, approaching that found in fuel cell operations, were performed on a scaled-up test bed. The bed demonstrated surprisingly good kinetics and other positive material properties. However, these studies also pointed to the need to develop new non-alkoxide based catalysts and doping methods to increase capacity and reduce the level of hydrocarbon impurities found in the desorbed hydrogen. For this reason, new Ti-Cl catalysts and doping processes are being developed which show higher capacities and improved kinetics. An overview of the current state-of-the-art will be presented along with our own studies and the implications for the viability of these materials in on-board hydrogen storage applications.

Keywords: Metal hydride; Complex hydride; Alanate; $\mathrm{NaAlH}_{4} ; \mathrm{Na}_{3} \mathrm{AlH}_{6}$;

Correspondence Address:

Karl J. Gross

Analytical Materials Science Department

Sandia National Laboratories

P.O. Box 969 MS 9403

Livermore, CA 94551-0969, U.S.A.

Tel. (925) 294-4639, Fax. (925) 294-3410

E-mail: kjgross@sandia.gov

RECEIVED

DEC 202000

U S.T.I 


\section{DISCLAIMER}

This report was prepared as an account of work sponsored by an agency of the United States Government. Neither the United States Government nor any agency thereof, nor any of their employees, make any warranty, express or implied, or assumes any legal liability or responsibility for the accuracy, completeness, or usefulness of any information, apparatus, product, or process disclosed, or represents that its use would not infringe privately owned rights. Reference herein to any specific commercial product, process, or service by trade name, trademark, manufacturer, or otherwise does not necessarily constitute or imply its endorsement, recommendation, or favoring by the United States Government or any agency thereof. The views and opinions of authors expressed herein do not necessarily state or reflect those of the United States Government or any agency thereof. 


\section{DISCLAIMER}

Portions of this document may be illegible in electronic image products. Images are produced from the best available original document. 


\section{Introduction}

The automobile industry appears set to introduce hydrogen-powered fuel-cell vehicles in the near future [1]. To be practical these vehicles will need a safe, lightweight and compact means of on-board hydrogen storage. Liquid, compressed gas and reformer-derived hydrogen all have well-known disadvantages [2]. For this reason, extensive efforts have been made to develop solid-state means of hydrogen storage, including metal hydrides [4,5] and, more recently nano-structured carbons [6,7]. Until recently the development of a high capacity, lightweight metal hydride that could be used to reversibly store hydrogen under ambient conditions seemed all but unattainable. That was until the pioneering work of Bogdanovic' and Schwickardi (1996) which showed that, by the addition of catalysts, the complex hydride $\mathrm{NaAlH}_{4}$ could be made to reversibly release and absorb approximately $4 \mathrm{wt} . \%$ hydrogen for over 30 cycles under moderate conditions [8]. Thus, catalyzed hydride complexes show the greatest promise for meeting the requirements of onboard hydrogen storage.

The synthesis of $\mathrm{LiAlH}_{4}$ in 1947 by Schlesinger [9] was followed by the discovery and study of many other complex hydrides [10-17]. $\mathrm{NaAlH}_{4}$ was first synthesized by the process of reacting $\mathrm{NaH}$ with $\mathrm{AlBr}_{3}\left(\mathrm{AlCl}_{3}\right)$ in a THF solution [18], then by direct synthesis of this compound from the elements under high-pressure hydrogen [19-21] and, eventually through direct melt synthesis without using any solvents [22]. While the potential use of complex hydrides for hydrogen storage had been considered [23], they were principally developed for use as convenient and efficient chemical reducing reagents [24]. However, in the more general class of saline hydrides, compounds such as lithium hydride and particularly calcium hydride, have been used for lightweight hydrogen storage for over half a century. As a typical example, $\mathrm{LiH}$ and $\mathrm{CaH}_{2}$ were widely employed as a portable means of storing hydrogen for inflating meteorological balloons [25]. However, in these examples, hydrogen is generated by reacting the hydride with water. This is a reaction that cannot be reversed in any efficient or practical manner.

Since Bogdanovic' and Schwickardi's discovery, there have been considerable efforts to develop new catalysts, advanced methods of doping and materials processing, as well as a better fundamental and practical understanding of the hydriding mechanisms. Many of the important properties of these materials and development of new catalysts (Ti- and $\mathrm{Fe}$ alcoholates, $(\mathrm{Fe}, \mathrm{Ni}) \mathrm{Cl}_{2},(\mathrm{~V}, \mathrm{RE}) \mathrm{Cl}_{3}, \beta-\mathrm{TiCl}_{3}$, and $\left.(\mathrm{Ti}, \mathrm{Zr}) \mathrm{Cl}_{4}\right)$ were the focus recent research by the group of Bogdanovic' [26] and, in particular, the Ph.D. thesis work of Tölle [27]. At the University of Hawaii, Jensen and co-workers have developed an advanced catalyst doping technique in which liquid alkoxide catalyst precursors are mechanically homogenized with purified solid $\mathrm{NaAlH}_{4}$. This method was used to produce materials with enhanced kinetics and improved reversible hydrogen capacities [28] compared with samples prepared using the original wet doping technique [8]. This homogenization technique was employed to dope $\mathrm{NaAlH}_{4}$ with a double catalyst consisting of 2 mol.\% each of the alkoxides $\mathrm{Zr}(\mathrm{Opr})_{4}$ and $\mathrm{Ti}\left(\mathrm{Ou}^{\mathrm{n}}\right)_{4}$. The two catalysts combined to give better overall dehydriding kinetics and a capacity of about $4.5 \mathrm{wt} . \%$ [29]. These improvements can be seen in the thermal programmed desorption (TPD) measurement of Figure 1. At McGill University, Zaluska and co-workers showed that hydrogen absorption and desorption kinetics coúld also be enhanced directly through mechanically grinding of the sodium alanates as well as by using carbon as an 
additive in the milling process [30]. That work that supported the notion that reduced particle size also plays an important role in improving kinetics. This idea was confirmed through the observation of kinetic enhancement when the catalyzed $\mathrm{NaAlH}_{4}$ particle size was decreased by precipitation using different solvents [26]. The mechanical milling technique was also employed to directly synthesis the alanates. This included the mechanical-alloying synthesis of $\mathrm{Na}_{3} \mathrm{AlH}_{6}, \mathrm{Na}_{2} \mathrm{LiAlH}_{6}[31], \mathrm{Li}_{3} \mathrm{AlH}_{6}$, and $(\mathrm{Li}-\mathrm{Na}-\mathrm{B})_{3} \mathrm{AlH}_{6}$ [32].

Collaborative research at Sandia National Laboratories (SNL) and the University of Hawaii (UH) has focused on the development and characterization of new hydrogen storage materials. In this paper we will present an overview of some of our most recent advances, including the development of new catalysts $[33,34]$.

It is critical for the ultimate use of complex hydrides as practical hydrogen storage materials to gain a complete understanding of the mechanisms by which hydrogen is absorbed and desorbed in these materials. Unlike, the classic interstitial metallic hydrides, $\mathrm{NaAlH}_{4}$ is believed to release hydrogen through a series of decomposition reactions [35-37]:

$$
\mathrm{NaAlH}_{4} \stackrel{3.7 w t \%}{\Leftrightarrow} 1 / 3 \mathrm{Na}_{3} \mathrm{AlH}_{6}+2 / 3 \mathrm{Al}+\mathrm{H}_{2} \Leftrightarrow \mathrm{wt. \%} \quad \text { total }=5.6 \mathrm{waH} . \%
$$

Dymova and co-workers were the first to make pressure vs. composition isotherm measurements (PCT) for the decomposition of undoped $\mathrm{NaAlH}_{4}$ [38]. Two separate plateaus appeared in their measurements corresponding to the two decomposition reactions of the Equation 1. We recently verified this two-step process in the solid-state decomposition of catalyzed $\mathrm{NaAlH}_{4}$ using dynamic in-situ x-ray diffraction [39]. Moreover, that study demonstrated the liquid-state decomposition of uncatalyzed $\mathrm{NaAlH}_{4}$ (melting temperature $180^{\circ} \mathrm{C}$ ) and showed that an additional polymorphic phase transition of $\mathrm{Na}_{3} \mathrm{AlH}_{6}$ may also occur as an intermediate decomposition step [40,41]. The PCT measurements of Dymova [38] and later Bogdanovic' [8] provided equilibrium pressures from which the heats of decomposition of $\mathrm{NaAlH}_{4}$ (liquid) and $\mathrm{Na}_{3} \mathrm{AlH}_{6}$ (solid) could be calculated. Equilibrium pressure measurements of the decomposition of $\mathrm{NaAlH}_{4}$ in the solid-state were made at Sandia National Laboratories [41] and also by Tölle and Bogdanovic' [26,27]. Advances in the catalytic activity of these materials now allow desorption measurements to be made down to room temperature [42]. These low temperature desorption measurements and, in particular, accurate van't Hoff analysis will be presented in this paper.

The other fundamental aspects of the decomposition/reformation processes that must be understood are the catalytic interactions and transport processes involved in these solid state reactions. The observations of the formation of sub-micron aluminum crystallites by dynamic in-situ X-ray diffraction experiments [39], as well as by a microscopic elemental analysis $[43,26,27]$ demonstrated the existence of long-range transport of metal atoms. Transport phenomenon, the effects of particle size, and catalytic activity are some of the subjects of ongoing investigations [40,43].

The net reaction of the equation 1 represents a theoretical reversible hydrogen capacity of 5.6 wt.\%. The equilibrium thermodynamics of these reactions indicate the potential to liberate all of this hydrogen at above 1 atmosphere of pressure and temperatures of $110^{\circ} \mathrm{C}$. Such an 
achievement would be extremely valuable for the on-board storage of hydrogen in lowtemperature fuel-cell vehicles. However, significant progress remains to be made in achieving the rapid hydrogen absorption and desorption kinetics required for vehicular applications. The work presented here summarizes recent cooperative activities between Sandia National Laboratories and the University of Hawaii to develop advanced catalyzed complex-hydride hydrogen-storage materials. In particular, our recent work focused on determining 1) the positive as well as the detrimental aspects of our current catalysts-doping procedures, 2) the development of new and improved catalysts, 3 ) engineering aspects and the fundamental properties of these materials. More details of our joint work on the catalyzed alanates can be found elsewhere in this volume $[33,34,40,43]$.

\section{Sample Preparation and Experimental Details}

Some results are reproduced here from published data of the work at the Max-Planck-Institut für Kohlenforschung and McGill University. Sample preparation for those results is described briefly in the figure captions and details can be found in the accompanying references. Much of the collaborative efforts of Sandia National Laboratories and the University of Hawaii were done using double catalysts of Ti- and $\mathrm{Zr}$-alkoxides. The homogenization technique developed at the University of Hawaii [28] was generally employed for sample preparation. This consisted of adding 2 mol.\% each of liquid $\mathrm{Ti}(\mathrm{OBu})_{4}$ and $\mathrm{Zr}(\mathrm{OPr})_{4}$ to solid $\mathrm{NaAlH}_{4}$ which had been purified from (THF) solution and vacuum dried. The mixture was ground together with a mortar and pestle and finally milled in a SPEX ${ }^{\circledR}$ mixer/mill for 30 seconds. Sandia National Laboratories also tested samples which were mechanically milled under argon for 3 and 8 hours, as well as samples which were doped with other catalysts (specifically; $\mathrm{Ti}_{3} \mathrm{Al}$ and $\beta-\mathrm{TiCl}_{3}$ ).

Low temperature kinetics, plateau pressures, and capacity measurement were obtained volumetrically using samples of approximately $1.5 \mathrm{~g}$ of catalyzed sample. Reversible hydrogen capacity data is presented in terms of wt.\% hydrogen normalized to the weight of the $\mathrm{NaAlH}_{4}$ only and does not include the weight of the catalysts [33]. Special air-less techniques were developed at Sandia National Laboratories to be able to characterize these catalyzed alanate materials using X-ray diffraction $[33,40]$, scanning electron microscopy (SEM), electron dispersive spectroscopy (EDS) and Auger elemental analysis [43].

Engineering property studies were performed at Sandia National Laboratories on a "scaleup" reactor bed designed to simulate the heat transfer and gas impedance conditions that might be found in real hydrogen storage applications. The bed was loaded with $100 \mathrm{~g}$ of $2 \mathrm{~mol} \%$ each Ti/Zr-Alkoxide catalyzed $\mathrm{NaAlH}_{4}\left(78 \mathrm{~g}\right.$ of $\mathrm{NaAlH}_{4}$ and $22 \mathrm{~g}$ of $\left.\mathrm{Ti}(\mathrm{OBu})_{4}+\mathrm{Zr}(\mathrm{OPr})_{4}\right)$ prepared in collaboration with the University of Hawaii [33].

\section{Thermodynamics}

Reasonably high kinetics at low temperatures allowed us to reliable determine equilibrium desorption plateau pressures down to room temperature for the $\mathrm{NaAlH}_{4}$ phase. These data are plotted in Figure 2 in the form of a van't Hoff plot $(\ln P$ vs $1 / T)$ and compared to the data previously published by the Bogdanovic' and co-workers [26]. Our low temperature data is a 
good agreement with the extrapolation of our previous high temperature data [41]. Thus, it has now been accurately shown that the temperature required for an equilibrium desorption pressure of 1 atma from $\mathrm{NaAlH}_{4}$ is $33^{\circ} \mathrm{C}$. This is a very convenient temperature for fuel-cell and other applications.

The $\mathrm{Na}_{3} \mathrm{AlH}_{6}$ plateau pressure is also shown in Figure 2. Because of the relatively low pressures and kinetics involved, the low-temperature $\mathrm{Na}_{3} \mathrm{AlH}_{6}$ van't Hoff data are not as reliable as the $\mathrm{NaAlH}_{4}$ data. Be that as it may, the 1 atma van't Hoff temperature for $\mathrm{Na}_{3} \mathrm{AlH}_{6}$ is estimated to be about $110^{\circ} \mathrm{C}$. This temperature is somewhat higher than desired for a PEM fuel cell and future work will aim at lowering this temperature. This can only be accomplished by direct modification of the thermodynamic properties of $\mathrm{Na}_{3} \mathrm{AlH}_{6}$.

\section{Kinetics}

Combined results from our recent investigations are compared with earlier data in the desorption measurements of Figure 3 and the absorption measurements of Figure 4. Some kinetics measurements are also shown from published data of the Max-Planck-Institut für Kohlenforschung and McGill University. Measurements were performed using different sample quantities, sample holders, and techniques. As will be shown later, thermal effects such as the heats of reaction and conductivity strongly influenced the kinetics preventing any quantitative comparisons. However, some general qualitative conclusions can be made. They can be summarized as follows. First, the combined results from these four independent laboratories validate the reversibility and high capacities of these materials regardless of the specific methods of sample preparation or catalysts used. In the worst case nearly $3 \mathrm{wt}$. \% of hydrogen can be desorbed at $125^{\circ} \mathrm{C}$ in three hours. On a weight basis this is nearly twice the capacity as current commercial metal hydrides under the same conditions. At higher temperatures $\left(160^{\circ} \mathrm{C}\right)$ the capacity increases to nearly $5 \mathrm{wt} . \%$ or three times better than commercial materials. The same in general comment can be made for hydrogen absorption (figure 4). In fact, surprisingly good kinetics can be achieved; curve c $\left(\beta-\mathrm{TiCl}_{3}\right.$ doped $\mathrm{NaAlH}_{4}$ ) absorbed over 4 wt. \% in less than one hour under the reasonably moderate conditions of 90 bar $\mathrm{H}_{2}$ and $100^{\circ} \mathrm{C}$.

Another observation, which is consistent between the desorption measurements, is the appearance of a break in the curves at around $3 \mathrm{wt}$. \%. This is due to the much slower kinetics of the second reaction (Eq. 1). Finally, it is apparent from these figures that both particle size and the type of catalysts used strongly influence the rates of hydrogen absorption and desorption.

Sandia National Laboratories together with the University of Hawaii initially examined the use of liquid alkoxide catalysts and the homogenization doping procedure. This has practical advantages over the "wet-chemistry" methods of doping the alanates in solution. Namely, the precipitation and drying steps are avoided and intimate mixing as well as particles reduction can be achieved through mechanical mixing and milling. However, we also found that the $\mathrm{Ti}+\mathrm{Zr}$ alkoxide catalyst doping procedure has significant drawbacks. These are: 1) the alkoxide based catalysts are heavy, $2 \mathrm{~mol}$. \% of each catalysts results in a $22 \mathrm{wt} . \%$ burden on the total material, 2) the liquid organometallic catalysts contaminate the desorbed hydrogen 
with hydrocarbons consisting mainly of a butane and propane, 3) oxygen from the decomposition of the alkoxide catalysts contaminates the active material, perhaps causing the less than the ideal $5.6 \mathrm{wt} . \%$ reversible capacity. All of these considerations lead to the need to develop non-hydrocarbon-based catalysts. For this reason, we are now investigating the catalytic properties of the titanium-halides. Recent experiments on $\mathrm{NaAlH}_{4}$ doped with $2 \mathrm{~mol} . \% \beta-\mathrm{TiCl}_{3}$ have shown reversible hydrogen capacities approaching the theoretical limit with no degradation in kinetic properties and no gas impurities (curves $c$ in figures 3 and 4 ) [33]. Using $\mathrm{x}$-ray diffraction, it was discovered that the $\beta-\mathrm{TiCl}_{3}$ catalyst precursor decomposes during the mechanical milling process to form $\mathrm{NaCl}$ and a dispersed titanium-based catalyst [40]. In a parallel investigation at the University of Hawaii, liquid $\mathrm{TiCl}_{4}$ was added by homogenization milling to give a reversible capacity of titanium-based catalysts is the focus of current investigations.

[34]. The nature of the

In addition to enhanced kinetics at $80-150^{\circ} \mathrm{C}$, we made the rather surprising observation that desorption could be measured even down to room temperature. As would be expected, the initial desorption rate was found to be strongly dependent on particle size. While the desorption rates are low $(0.016 \mathrm{wt} . \% / \mathrm{hr}$.), room temperature desorption from these highcapacity materials should prove very interesting for certain low-rate hydrogen-powered applications.

\section{Cyclic Stability}

The initial desorption from the alkoxide catalyzed samples gave gas capacities in excess of the theoretical $5.5 \mathrm{wt} . \%$ value (6 wt.\%). This is believed to come from large quantities of impurities gases derive from the alkoxide catalyst precursors in addition to the desorbed hydrogen. Further cycles demonstrate a lower-than-expected capacity for all of the samples we have tested with the liquid alkoxide catalysts (both absorption and desorption capacities were about $3 \mathrm{wt. \% )}$. X-ray diffraction measurements clearly showed that the low capacity is due mainly to an inability to completely recharge to a composition of $100 \% \mathrm{NaAlH}_{4}$. X-ray diffraction measurements also demonstrated that the samples could be fully desorbed to sodium hydride and aluminum. The mechanism for this incomplete recharging phenomenon is uncertain at the present time. It may involve inhomogeneous distribution of the catalysts or impurity effects. However, this capacity problem has been overcome through the application of titanium-halide catalysts.

\section{Practical Studies, Applications Oriented Materials Properties}

A scaleup bed containing $100 \mathrm{~g}$ of $\mathrm{NaAlH}_{4}$ doped with Ti- and $\mathrm{Zr}$-alkoxides ( 2 mol.\% each) was tested at Sandia National Laboratories. The bed was cycled through five absorption/desorption cycles. Absorption $\mathrm{H}_{2}$ pressures generally ranged from 100-200 atm and nominal absorption temperatures ranged from $125-165^{\circ} \mathrm{C}$. Desorption was generally performed at $150-165^{\circ} \mathrm{C}$ against a $1 \mathrm{psig}(1.07 \mathrm{atma})$ backpressure. In addition to capacity and rate measurements, exothermic (charging) and endothermic (discharging) thermal effects were recorded. The desorbed hydrogen was monitored for gaseous impurities and a small sample was removed after the fourth desorption cycle for XRD and SEM/EDS analysis. The volume change of the alanate was measured over the last desorption half-cycle. Detailed results from 
these tests are presented in an accompanying paper [33]. The following are some highlights of that study.

\subsection{Discharge and Recharge Rates}

Desorption of hydrogen occurred rapidly at $150-165^{\circ} \mathrm{C}$, with about two thirds of the hydrogen (30 SL) discharging in 3 hours. For the absorption of hydrogen a range of applied pressures and starting temperatures were tried $\left(125-165^{\circ} \mathrm{C}, 122-210 \mathrm{bar}\right)$. In all cases charging was more rapid than we had expected. Most of the hydrogen was absorbed in the first hour or two, even for the lowest pressure and starting temperature $\left(125^{\circ} \mathrm{C}, 122 \mathrm{bar}\right)$. Charge and discharge curves for the scaleup bed are also included in Figures 4 and 5 (curves $\mathrm{f}$ ).

\subsection{Thermal Effects}

The higher than expected initial charging kinetics, combined with limited heat transfer, resulted in exothermic temperature excursions (Figure 5), as is common with many hydrides. A hydrogen pressure of 174 bar was applied to the fully dehydrided bed which had been equilibrated to $155^{\circ} \mathrm{C}$. Within one minute, the exothermic hydriding reaction resulted in an internal temperature of $234^{\circ} \mathrm{C}$ (the van't Hoff temperature for $\mathrm{NaAlH}_{4}$ at this pressure). This is above the melting point of $\mathrm{NaAlH}_{4}\left(182^{\circ} \mathrm{C}\right)$. Therefore, any $\mathrm{NaAlH}_{4}$ produced during this high-temperature excursion forms directly into the liquid phase. After this initial excursion a thermal arrest occurs at $182^{\circ} \mathrm{C}$ due to solidification (Figure 5). This demonstrates that liquid $\mathrm{NaAlH}_{4}$ was formed during the initial charge.

It is natural to ask if such melting could be detrimental to the subsequent performance of the alanate bed. Our observations indicated no negative effects of partially melting the bed at least three times. In fact, partial melting may be beneficial. We opened the reactor between cycles 4 and 5 and found the bed to be sintered into a porous, solid mass. Such a structure may have distinct advantages for actual applications. In particular, such a sintered structure should reduce particulate migration, increase packing densities, allow expansion, provide a constant internal gas impedance and enhance safety.

\subsection{Hydriding Volume Changes}

In the classic metal hydrides, large volume changes associated with lattice expansion during hydride formation poses significant engineering problems Therefore, the volume change of the active material in the scaleup bed was measured from the beginning to the end of fifth desorption cycle. The volume contracted by-14.7\%, which is reasonably close to the theoretical value calculated from X-ray densities for the complete dehydriding reaction (-16.5 \%) [33]. Unlike the traditional hydrides, the alanates have the distinct advantage of starting with the material in its fully hydrided state. Fully packed beds can be constructed, which simplifies bed design and allows a higher volumetric density to be achieved.

\subsection{Impurity Gases}


The composition of the desorption gases were examined regularly by RGA (Residual Gas Analysis [Mass Spectroscopy]) and occasionally using GC (Gas Chromatography). Typical RGA patterns of the desorption gasses showed not only hydrogen but also significant impurities along with the ubiquitous background RGA peaks for $\mathrm{H}_{2} 0, \mathrm{CO}$ and $\mathrm{CO}_{2}$. GC analysis taken after the second cycle showed that butane and propane were present in the hydrogen. Thus, it appears that the liquid $\mathrm{Ti}\left(\mathrm{OBu}^{\mathrm{n}}\right)_{4}$ and $\mathrm{Zr}(\mathrm{OPr})_{4}$ catalysts decompose and release significant amounts of hydrocarbon impurities. PEM fuel cells are not very tolerant of impurity gases, especially hydrocarbons that lead to the formation of $\mathrm{CO}$. These results led us to concentrate on the development of inorganic catalysts.

\section{Fundamental Studies, Catalysis and Transport Mechanisms}

The SEM images of Figure 6 show the pronounced changes in morphology that occur during the two-stage desorption of $\mathrm{NaAlH}_{4}$ (Eq.1). This is an indication of the segregation of the constituent phases. Surface EDS analysis was also used to examine impurities effects on the samples. Measurements taken after the homogenization process also clearly showed the presence of large amounts of residual oxygen introduced by the $\operatorname{Ti}\left(\mathrm{OBu}^{\mathrm{n}}\right)_{4}+\mathrm{Zr}(\mathrm{OPr})_{4}$ catalysts [43].

The growth of relatively narrow diffraction peaks from aluminum have been observed through in-situ $\mathrm{x}$-ray diffraction measurements made during the decomposition of both catalyzed and catalyzed $\mathrm{NaAlH}_{4}$ (Figure 7) [39]. Thus, aluminum must segregate according to equation 1 to form crystallites with dimensions on the order of $1000 \AA$ or larger. This implies the longrange transport of metal species. Surface EDS verified this notion by showing an increasing overall aluminum concentration on the surface of the powder particles during decomposition [36]. In addition, Auger spectra analysis shows on that most of the catalyst remains on the material's surface [39]. This raises the question of how aluminum hydride anions paired with sodium cations in an ionic solid could be influenced by catalytic sites that are immobilized on the particle surface. One speculation is that the transported species is a more mobile hydride such as $\mathrm{AlH}_{3}$ [39]. The low melting point of $\mathrm{NaAlH}_{4}$ demonstrates the weak nature of the ionic bond. It is possible that local disproportionation of $3 \mathrm{NaAlH}_{4}$ into $\mathrm{Na}_{3} \mathrm{AlH}_{6}$ and $2 \mathrm{AlH}_{3}$ takes place. The $\mathrm{AlH}_{3}$ then transports to the catalytic site where it dissociates into $\mathrm{Al}$ and $\mathrm{H}_{2}$. However, none of these mechanistic concepts have been verified experimentally.

\section{Conclusion and Outlook}

This overview has covered some of the recent advances in the development of catalyzed sodium-alanates as lightweight hydrogen storage materials. These materials are now realizing reversible capacities in excess of $4.2 \mathrm{wt} . \%$. The current state of the art allows the desorption of $3 \mathrm{wt} . \%$ hydrogen in a little over one hour at $125^{\circ} \mathrm{C}$. Precise plateau pressure measurements demonstrate that thermodynamically these materials are ideally suited to practical applications. The $\mathrm{NaAlH}_{4} \Leftrightarrow 1 / 3 \mathrm{Na}_{3} \mathrm{AlH}_{6}+2 / 3 \mathrm{Al}+\mathrm{H}_{2}$ reaction delivers $1 \mathrm{~atm}$ hydrogen at $33^{\circ} \mathrm{C}$.

These are important achievements; however, a great deal of progress remains to be made. In particular, 1) the slow dehydriding and rehydriding kinetics remain a significant barrier to 
applications such as fuel cell vehicles. Titanium-halide catalysts and dry doping procedures are showing promise, especially in overcoming the impurity and capacity relates restraints the previous alkoxide based catalysts, but the kinetics must still be improved. 2) Completing the second reaction step $1 / 3 \mathrm{Na}_{3} \mathrm{AlH}_{6}+2 / 3 \mathrm{Al}+\mathrm{H}_{2} \Leftrightarrow \mathrm{NaH}+\mathrm{Al}+3 / 2 \mathrm{H}_{2}$ is necessary to obtain the full $5.6 \mathrm{wt} . \%$ theoretical capacity. Unfortunately, $\mathrm{Na}_{3} \mathrm{AlH}_{6}$ is a little too stable for many applications; releasing $1 \mathrm{~atm}$ hydrogen at about $110^{\circ} \mathrm{C}$. Elemental substitution must be explored as a means to de-stabilize this reaction. 3) Long-term cycling studies will be needed to ensure the viability of these materials for reversible hydrogen storage. 4) Safety is an important issue that must be addressed. These compounds are highly reactive with water and air. Small amounts of water or oxygen as impurities are unlikely to be a significant problem. However, engineering solutions or material modifications will be required to reduce the hazards associated with a full exposure to air or water. 5) Finally, progress has been made in understanding the fundamental processes that take place in these solid-state reactions. Longrange transport of metal species appears to play an important role in the overall reaction kinetics. For the moment, however, the nature of the transported species and the role of the catalysts remain a mystery.

\section{Acknowledgements}

Funding for this project is provided by the by the U.S. Department of Energy, Office of Power Technologies, Hydrogen Program Office under contract No. DE-AC36-83CH10093. We wish to acknowledge the valuable contributions of Gary Sandrock of SunaTech, Inc. through work performed at Sandia National Laboratories in Livermore. We wish to thank Don Meeker, Nancy Yang, Ken Stewart, and Tim Sage of Sandia National Laboratories for their contributions in all aspects of the experimental work and instrumentation. 


\section{References}

[1] An official reference regarding the demonstration of fuel cell vehicles.

[2] A reference describing the limitations of liquid and compressed gas and reformer hydrogen storage Technology's.

[3] Sandrock, G., J. Alloys and Compounds, 293-295 (1999) 877.

[4] Sandrock, G., Suda, S., and Schlapbach, L., in Schlapbach, L. (ed.), Hydrogen in Intermetallic Compounds II, Topics in Applied Physics, Vol. 67, Springer-Verlag,1992, Chap. 5, p. 197.

[5] Dillion, A.C., Jones, K.M., Bekkedahl, T.A., Kiang, C.H., Bethune, D.S., and Heben, M., Nature 386 (1997) 377.

[6] Park, C., Anderson, P.E., Chambers, A., Tan, C.D., Hidago, R., and Rodriquez, N.M., J. Phys. Chem. B103 (1999) 10572.

[7] Liu, C., Fan, Y.Y., Liu, M., Wei, Y.-L., Lu, M.-Q., Cheng, H.-M., and Dresselhaus, M.S., Science 286 (1999) 1127.

[8] Bogdanovic, B. and M. Schwickardi, J. Alloys and Compounds, 253 (1997) 1.

[9] Finholt, A.E., Bond Jr. A.C., and Schlesinger, H.I., Journal American Chemistry Society, 69 (1947) 1199.

[10] Ashby, E. C. "The Chemistry of Complex Aluminohydrides", Advances in Inorganic Chemistry and Radiochemistry, series editors H. J. Emeléus and A. G. Sharp, New York, Academic Press. 8 (1966) 283.

[11] Finholt, A.E., Helling, C., Imhof, V., Nielsen, L. and Jacobson,E., Inorganic Chemistry, 2(3) (1963) 317.

[12] Erlich, R., J. Amer. Chem. Soc. 88 (1966) 858.

[13] Chini, P., A. Baradel, and Vacca, C., La Chimica E LIndustria, 48(6) (1966) 596.

[14] Zakharkin, L.I. and Gavrilenko, V.V., Doklady Akad. Nauk. SSSR,, 145 (1962) 793.

[15] Dymova, T. N., V. N. Konoplev, et al. Russian J. Coordination Chemistry, 25(5) (1999) 312.

[16] Claudy, P., Bonnetot, B., and Letoffe, J.M., J. Thermal Analysis, 15(1) (1979) 119.

[17] Wiberg, E., R. Bauer, et al. Z. Naturforsch, B 6 (1951) 393.

[18] Finholt, A.E., Barbaras, G.C., Barbaras, G.K., Urry, G., Wartik, T., and Schlesinger, H.I., J. Inorganic Nuclear Chemistry, 69 (1955) 317.

[19] Ashby, E.C., Chem. Ind., (1962) 208.

[20] Ashby, E.C., J. Organometal. Chem., 200 (1980) 1.

[21] Clasen, H.V., Angew, Chemistry, 74(10) (1961) 322.

[22] Dymova, T.N., Eliseeva, N.G., Bakum, S.I., and Dergachev, Y.M., Doklady Akademii Nauk. SSSR, UDC 546.07, 215(6) (1974) 1369.

[23] Wiswall, R., Hydrogen Storage in Metals, Springer-Verlag (1978) 201.

[24] Ashby, E. C. and Lin, J. J., J. Organic Chemistry, 43(13) (1978) 2567.

[25] Gibb Jr., T.R.P., J. Chemical Education - New England Association of Chemistry Teachers, 25 (1948) 577.

[26] Bogdanovic', B., Brand, R.A., Marjanovic', A., Schwikardi, M., and Tölle, J., J. Alloys and Compounds, 302(2000) 36.

[27] Tölle, J., Ph.D Thesis, Ruhr-Universität Bochum, Germany, (1998). 
[28] Jensen, C.M., Zidan, R.A., Mariels, N., Hee, A.G., and Hagen, C.. Int. J. Hydrogen Energy, 24 (1999) 461.

[29] Zidan, R.A., Takara, S., Hee, A.G., and Jensen, C.M.. J. Alloys and Compounds, 285 (1999) 119.

[30] Zaluska, A., Zaluski, L., and Ström-Olsen, J.O., J. Alloys and Compounds, 298 (2000) 125.

[31] Huot, J. , Boily, S., Güther, V., and Schulz, R., J. Alloys and Compounds, 283 (1999) 304.

[32] Zaluska, A., Zaluski, L., and Ström-Olsen, J.O., J. Alloys and Compounds, 290 (1999) 71.

[33] Sandrock, G., Gross, K., Thomas, G., Jensen, C., Meeker, D., and Takara, S., "Engineering considerations in the use of catalyzed sodium alanates for hydrogen storage", these Proceedings.

[34] Lewandowski, B., Seidl, T., Takara, S., Sun, D., and Jensen, C., "Dissociation/reassociation kinetics of catalytically enhanced $\mathrm{NaAlH}_{4}$ ", these Proceedings.

[35] Ashby, E.C. and Kobetz, P., Inorganic Chemistry, 1966, 5(9) p. 1615-1617.

[36] Zakharkin, L.I., Gavrilenko, V.V., Antipin, L.M., and Struchkov, Y.T., Zhur. Neorg. Khim., 12 (1967) 1148.

[37] Dilts, D.A. and Ashby, E.C., Inorg. Chem., 11(6) (1972) 1230.

[38] Dymova, T.N., Dergachev, Yu.M., Sokolov, V.A., and Grechanaya,N.A., Doklady Akademii Nauk SSSR, UDC 546.11 224(3) (1974) 591.

[39] Gross, K.J. , Guthrie, S.E., Takara, S., and Thomas, G.J., J. Alloys and Compounds, 297 (2000) 270.

[40] Gross, K.J. , and Thomas, G.J. , "Real Time X-ray Diffraction of Catalyzed Alanates", these Proceedings.

[41] Thomas, G.J., Guthrie, S.E., and Gross, K., 'Hydride development for hydrogen storage', in Proceedings U.S. DOE Hydrogen Program Review (1999), NREL/CP-570-26938,452. Denver CO.

[42] Gross, K., Thomas, G.J., and Sandrock, G., 'Hydride development for hydrogen storage', in Proceedings U.S. DOE Hydrogen Program Review (2000), San Ramon, CA.

[43] Thomas, G. J., Gross, K. J., and Yang, N.Y.C., 'Microstructural characterization of catalyzed $\mathrm{NaAlH}_{4}$, these Proceedings.

\section{Figure Captions}

Figure 1. Thermal programmed desorption $\left(2{ }^{\circ} \mathrm{C}\right.$ min-1) of hydrogen from $\mathrm{NaAlH}_{4}$ doped using different catalysts and doping methods. Measurements were made following 3 full dehydriding/rehydriding cycles.

Figure 2. Van't Hoff Diagram showing equilibrium pressures as a function of temperature for the $\mathrm{NaAlH}_{4} \Leftrightarrow 1 / 3\left(\alpha-\mathrm{Na}_{3} \mathrm{AlH}_{6}\right)+2 / 3 \mathrm{Al}+\mathrm{H}_{2}$ and the $\alpha-\mathrm{Na}_{3} \mathrm{AlH}_{6} \Leftrightarrow 3 \mathrm{NaH}+\mathrm{Al}+3 / 2 \mathrm{H}_{2}$ reactions. Samples doped with 2 mol.\% each of the liquid catalysts of $\mathrm{Ti}\left(\mathrm{OBu}^{\mathrm{n}}\right)_{4}$ and $\mathrm{Zr}(\mathrm{OPru})_{4}$ 
Figure 3. A compilation of $\mathrm{NaAlH}_{4}$ hydrogen desorption kinetics measurements from different authors. a) $1^{\text {st }}$ desorption $\left(25-150^{\circ} \mathrm{C}\right)$ of $2 \mathrm{~g} \mathrm{NaAlH} 4$ doped by mechanical milling for three hours with 2 mol.\% each of the liquid catalysts of $\mathrm{Ti}\left(\mathrm{OBu}^{\mathrm{n}}\right)_{4}, \mathrm{Zr}(\mathrm{OPr})_{4}$ and $2 \mathrm{~mol} . \%$ solid $\mathrm{Ti}_{3} \mathrm{Al}(\mathrm{SNL})$, b) $1^{\text {st }}$ desorption $\left(25-150^{\circ} \mathrm{C}\right)$ and $4^{\text {th }}$ desorption $\left(125^{\circ} \mathrm{C}\right)$ of sample processed as in a) but without solid $\mathrm{Ti}_{3} \mathrm{Al}$ catalyst (SNL/UH), c) $3^{\text {rd }}$ desorption $\left(125^{\circ} \mathrm{C}\right)$ of $2 \mathrm{~g}$ $\mathrm{NaAlH}_{4}$ doping by mechanical milling for three hours with $2 \mathrm{~mol} \% \beta-\mathrm{TiCl}_{3}$ (SNL), d) desorption $\left(80,100,120,150^{\circ} \mathrm{C}\right)$ of $\mathrm{NaAlH}_{4}$ milled together with $10 \mathrm{wt}$. $\%$ carbon for 2 hours $[30]$, e) $1^{\text {st }}$ desorption $\left(120^{\circ} \mathrm{C}\right.$ and $\left.150^{\circ} \mathrm{C}\right)$ of $\mathrm{NaAlH}_{4}$ precipitated from $\mathrm{THF}$ using pentane then doped with $2 \mathrm{~mol} . \% \mathrm{Ti}(\mathrm{OBu})_{4}$ in toluene, filtered and dried under vacuum [26], f) $1^{\text {st }}$ desorption $\left(50-160^{\circ} \mathrm{C}\right)$ of $100 \mathrm{~g}$ scaleup bed $\mathrm{NaAlH}_{4}$ doped by mechanical mixing for $30 \mathrm{sec}$. with 2 mol.\% each of the liquid catalysts of $\mathrm{Ti}\left(\mathrm{OBu}^{\mathrm{n}}\right)_{4}$ and $\mathrm{Zr}(\mathrm{OPr})_{4}(\mathrm{SNL} / \mathrm{UH})$.

Figure 4. A compilation of $\mathrm{NaAlH}_{4}$ hydrogen absorption kinetics measurements from different authors. a) $6^{\text {th }}$ absorption $\left(125^{\circ} \mathrm{C}, 67\right.$ bar) of $2 \mathrm{~g} \mathrm{NaAlH} 4$ doped by mechanical milling for three hours with 2 mol.\% each of the liquid catalysts of $\mathrm{Ti}\left(\mathrm{OBu}^{\mathrm{n}}\right)_{4}, \mathrm{Zr}(\mathrm{OPr})_{4}$ and 2 mol.\% solid $\mathrm{Ti}_{3} \mathrm{Al}$ (SNL), b) $3^{\text {rd }}$ absorption $\left(125^{\circ} \mathrm{C}, 68\right.$ bar) of sample processed as in a) but without solid $\mathrm{Ti}_{3} \mathrm{Al}$ catalyst (SNL/UH), c) $2^{\text {nd }}$ absorption $\left(125^{\circ} \mathrm{C}, 91\right.$ bar) and $4^{\text {th }}$ absorption $\left(100^{\circ} \mathrm{C}, 90 \mathrm{bar}\right)$ of $2 \mathrm{~g} \mathrm{NaAlH}_{4}$ doping by mechanical milling for three hours with $2 \mathrm{~mol} \% \mathrm{\beta}$ $\mathrm{TiCl}_{3}$ (SNL), d) absorption $\left(80,120,150^{\circ} \mathrm{C} 89\right.$ bar) of $\mathrm{NaAlH}_{4}$ milled together with 10 wt.\% carbon for 2 hours [30], e) $8^{\text {th }}$ absorption (104 ${ }^{\circ}, 83$ bar) of $\mathrm{NaAlH}_{4}$ precipitated from THF using pentane then doped with $2 \mathrm{~mol} \% \mathrm{Ti}(\mathrm{OBu})_{4}$ in toluene, filtered and dried under vacuum $[27]$, f) $4^{\text {th }}$ absorption $\left(160^{\circ} \mathrm{C}, 174 \mathrm{bar}\right)$ of $100 \mathrm{~g}$ scaleup bed $\mathrm{NaAlH}_{4}$ doped by mechanical mixing for $30 \mathrm{sec}$. with 2 mol.\% each of the liquid catalysts of $\mathrm{Ti}\left(\mathrm{OBu}^{\mathrm{n}}\right)_{4}$ and $\mathrm{Zr}(\mathrm{OPr})_{4}$ (SNL/UH).

Figure 5. Temperature excursion in $100 \mathrm{~g}$ scaleup test bed during the fourth hydrogen absorption cycle (initial: $\mathrm{T}=160^{\circ} \mathrm{C}, \mathrm{P}=174$ bar).

Figure 6. SEM images showing changes in morphology that occur during the decomposition of $\mathrm{NaAlH}_{4}$ doped with 2 mol.\% each of the liquid catalysts of $\mathrm{Ti}\left(\mathrm{OBu}^{\mathrm{n}}\right)_{4}$ and $\mathrm{Zr}(\mathrm{OPru})_{4}$.

Figure 7. Dynamic in-situ $\mathrm{x}$-ray diffraction measurements taken during decomposition of $\mathrm{NaAlH}_{4}$ mechanically mixed with 2 mol.\% each of the liquid catalysts of $\mathrm{Ti}\left(\mathrm{OBu}^{\mathrm{n}}\right)_{4}$ and $\mathrm{Zr}(\mathrm{OPrn})_{4}$. 


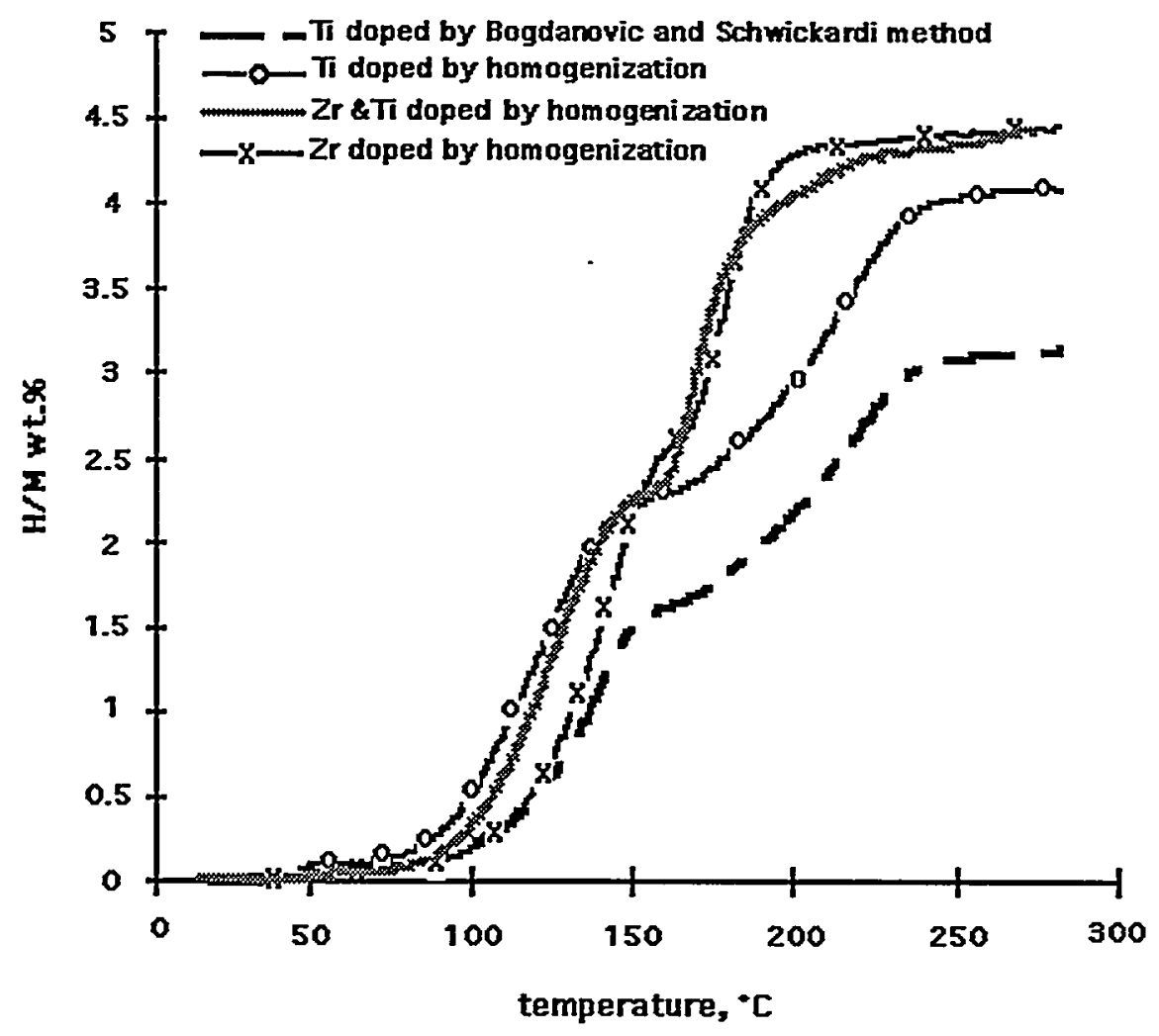

Figure 1. 


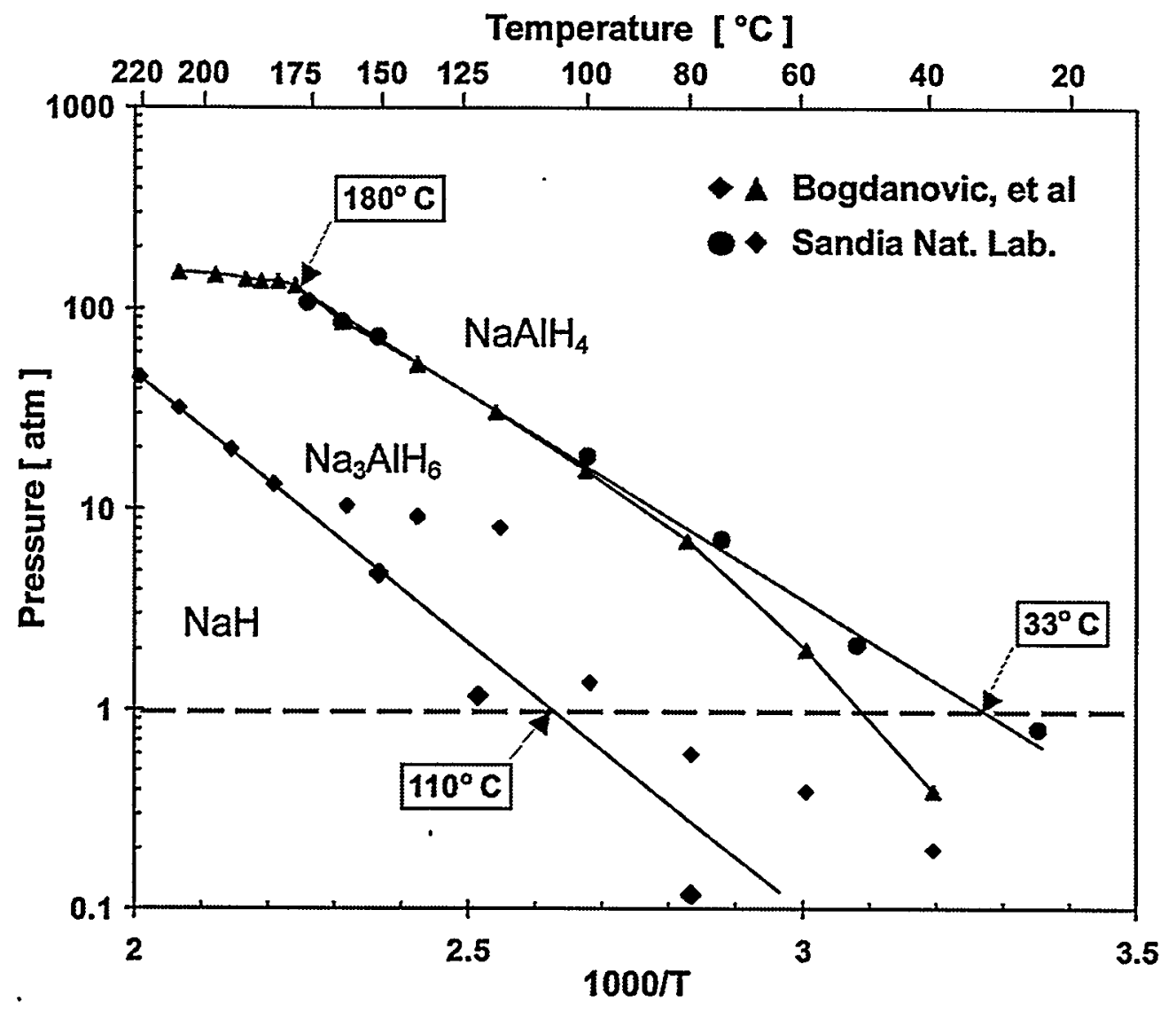

Figure 2. 


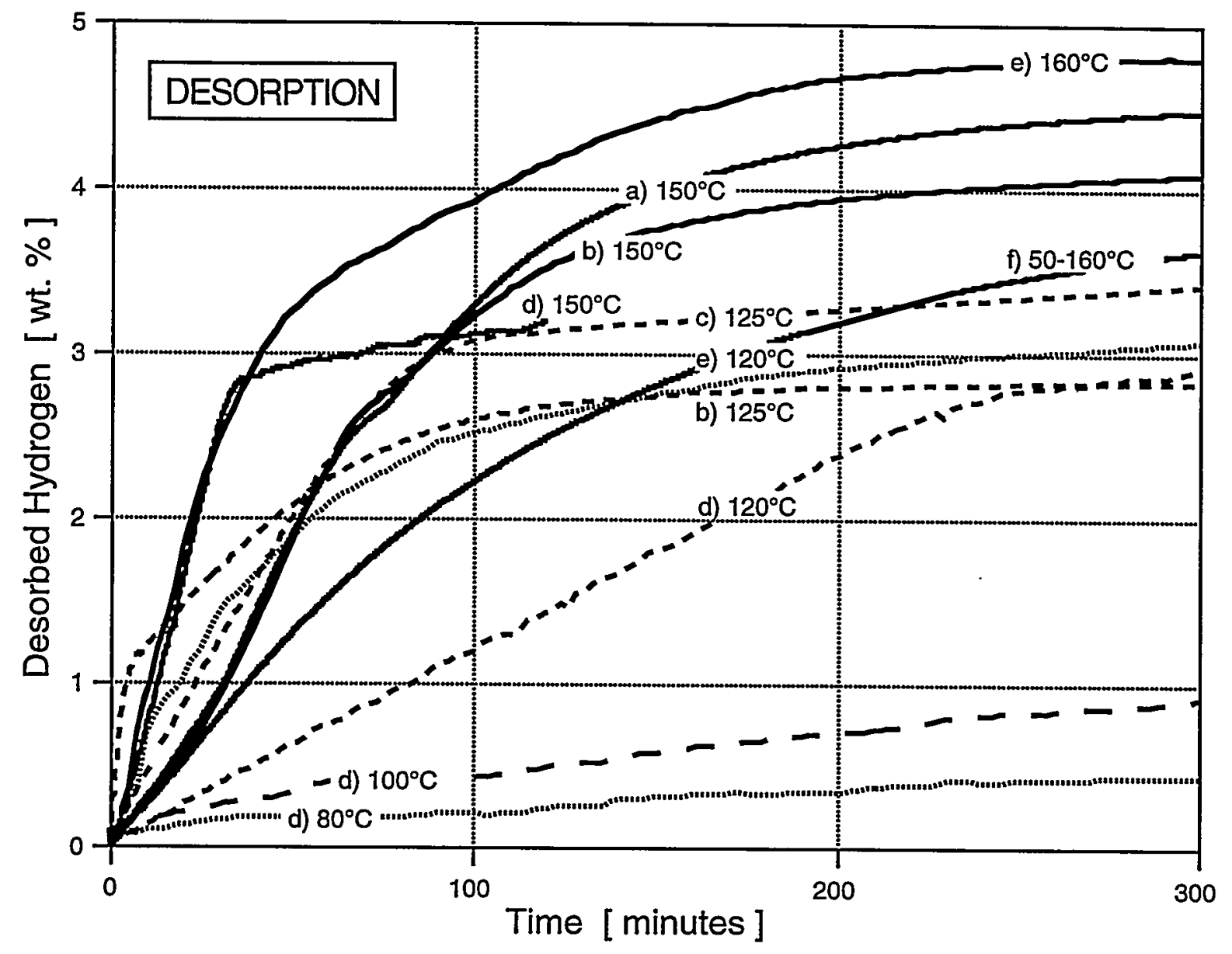

Figure 3. 


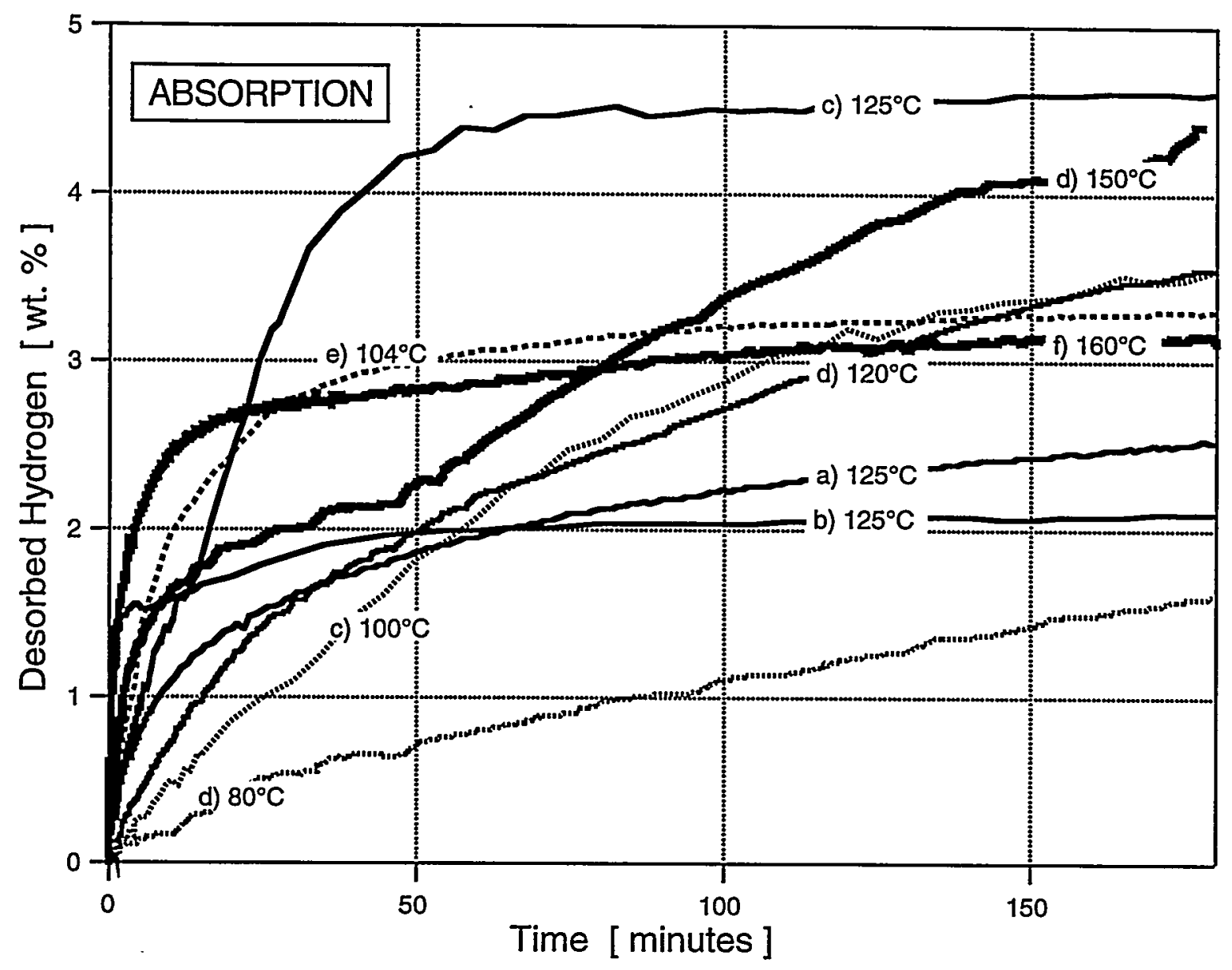

Figure 4. 


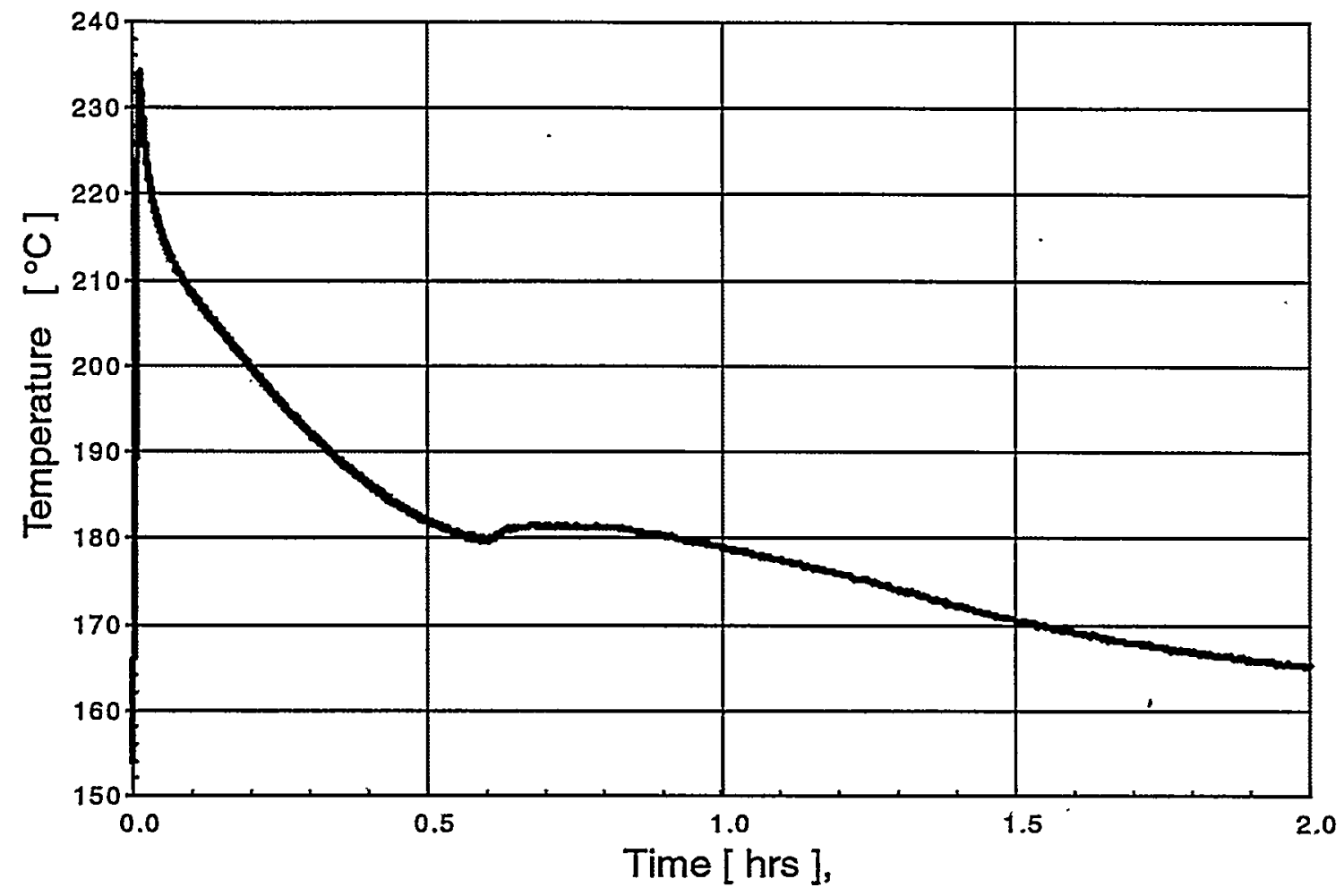

Figure 5.
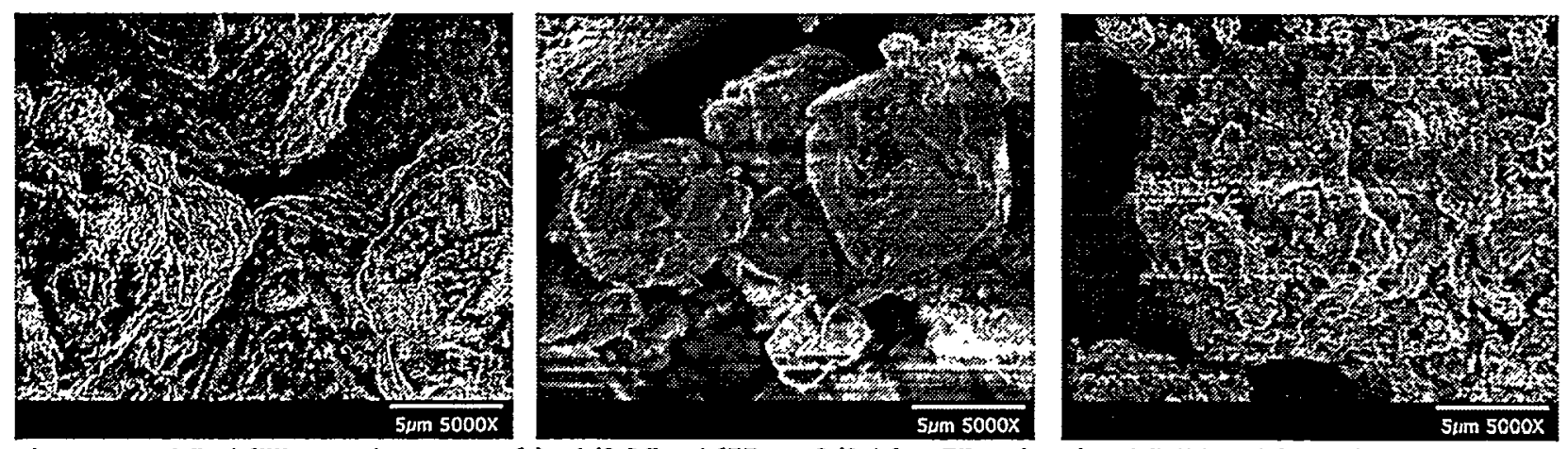
a)
$\mathrm{NaAlH}_{4}$
b) $1 / 3 \mathrm{Na}_{3} \mathrm{AlH}_{6}+2 / 3 \mathrm{Al}+\mathrm{H}_{2} \Rightarrow$
c) $\mathrm{NaH}+\mathrm{Al}+3 / 2 \mathrm{H}_{2}$

Figure 6. 


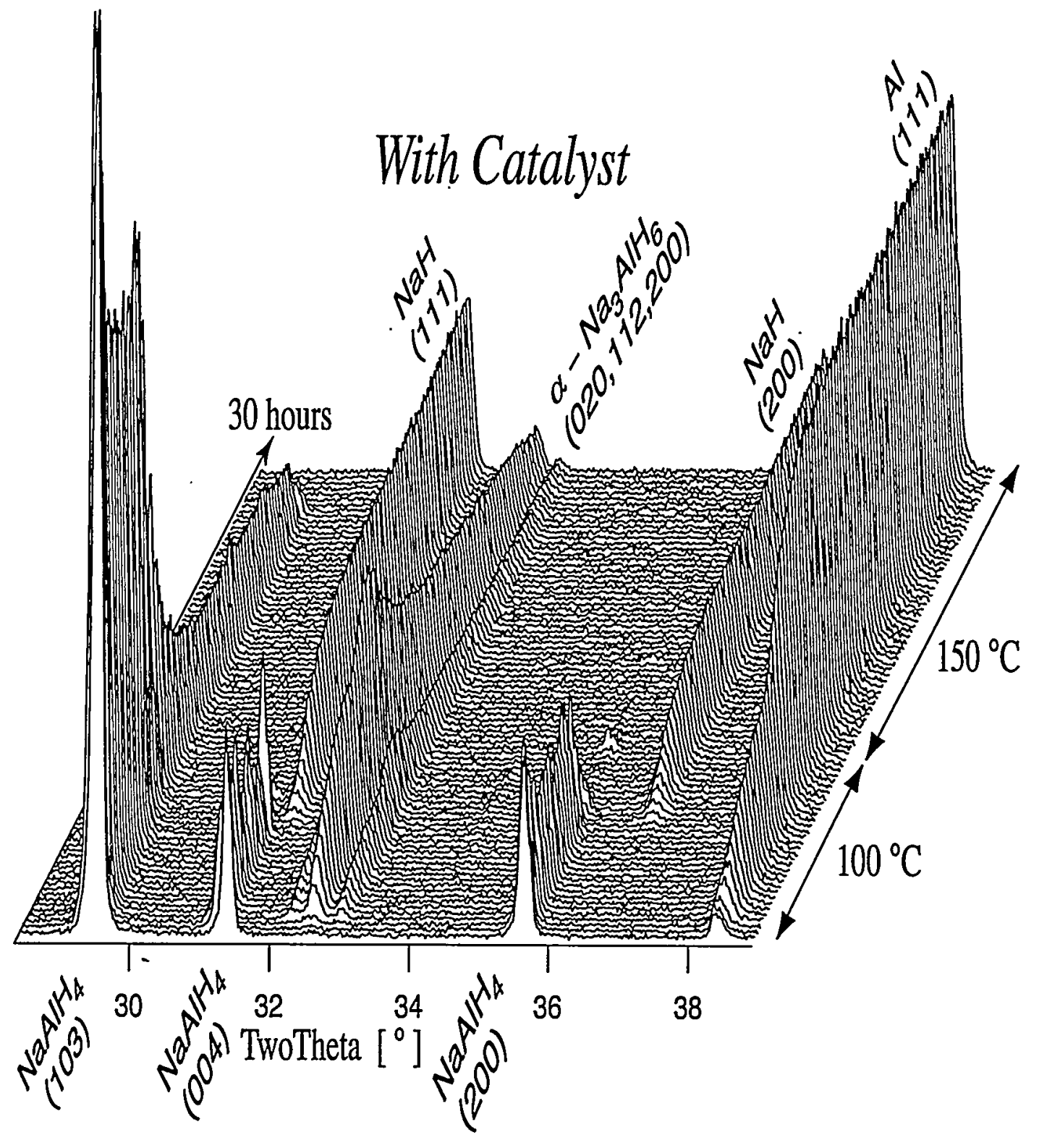

Figure 7. 